\title{
Padding Required: Assessing the Economic Impact of the Super Bowl
}

\author{
Victor A. Matheson \\ and \\ Robert A. Baade
}

September 2004

\section{COLLEGE OF THE HOLY CROSS, DEPARTMENT OF ECONOMICS \\ FACULTY RESEARCH SERIES, WORKING PAPER NO. 04-03*}

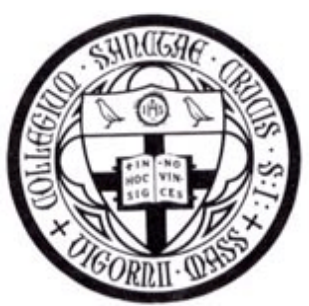

Department of Economics

College of the Holy Cross

Box 45A

Worcester, Massachusetts 01610

(508) 793-3362 (phone)

(508) 793-3710 (fax)

http://www.holycross.edu/departments/economics/website

*All papers in the Holy Cross Working Paper Series should be considered draft versions subject to future revision. Comments and suggestions are welcome. 


\title{
Padding Required: Assessing the Economic Impact of the Super Bowl
}

\author{
Victor A. Matheson ${ }^{\dagger}$ \\ College of the Holy Cross \\ and \\ Robert A. Baade ${ }^{\dagger \dagger}$ \\ Lake Forest College
}

September 2004

\begin{abstract}
Civic boosters generally have estimated the Super Bowl to have an impact of $\$ 300$ to $\$ 400$ million on a host city's economy. The National Football League has used the promise of an economic windfall to convince skeptical cities that investments in new stadiums for their teams in exchange for the right to host the event makes economic sense. Evidence from host cities from 1970-2001 indicates the Super Bowl contributes approximately one-quarter of what the boosters have promised and that the game could not have contributed by any reasonable standard of statistical significance, more than \$300 million to host economies.
\end{abstract}

JEL Classification Codes: L83, R53

Keywords: football, impact analysis, Super Bowl, sports, mega-event

${ }^{\dagger}$ Victor A. Matheson, Department of Economics, Box 157A, College of the Holy Cross, Worcester, MA 01610-2395, 508-793-2649 (phone), 508-793-3710 (fax), vmatheso@holycross.edu

${ }^{\dagger}$ Robert A. Baade, Department of Economics and Business, Lake Forest College, Lake Forest, IL 60045, 847-735-5136 (phone), 847-735-6193 (fax), baade@lfc.edu 


\section{INTRODUCTION}

A joint study conducted by the National Football League (NFL) and the Sport Management Research Institute (SMRI) of Westin, Florida estimated an economic impact of \$393 million from Super Bowl XXXIII on the South Florida economy (NFL, 1999). If those

numbers are accurate, "Super" is an apt adjective for the event. Only the Summer Olympic Games can seriously be thought to generate an impact of such magnitude for a short-term sporting event. Reasons for skepticism, however, abound, and one may well need look no further than the NFL's motivation for making such lofty claims. Can a study either commissioned or performed by the NFL be unbiased if the NFL has used the promise of a future Super Bowl as an enticement for cities to build new facilities? Modern sports stadiums generally receive some form of public funding, and the NFL at least indirectly has rationalized public financial support on the grounds that the economic impact from a single Super Bowl approximates the cost of building a new stadium. Coincidence? The purpose of this study is to estimate the economic impact of Super Bowls from 1970 through 2001. The results indicate that the economic impact of the Super Bowl is likely on average one-quarter or less the magnitude of the most recent NFL estimates.

\section{REVIEW OF SUPER BOWL IMPACT STUDIES}

The economic impact estimates for the Super Bowl extend from one intellectual end zone to the other. The NFL-SMRI study is the most optimistic appraisal attributing a $\$ 670$ million increase in taxable sales in South Florida (Miami-Dade, Broward, and Palm Beach counties) and an increase in economic activity of $\$ 396$ million to the event (NFL, 1999). Tacitly, the NFL- 
commissioned study envisioned a horde of affluent spendthrifts descending on the three-county area. The NFL-SMRI team reported that the average income of Super Bowl attendees is more than twice that of the average visitor to South Florida during the peak tourist months of January and February ( $\$ 144,500$ compared to $\$ 40,000-\$ 80,000)$, and they spend up to four times as much as the average visitor to South Florida ( $\$ 400.33$ per day compared to $\$ 99-\$ 199$ per day). Jim Steeg, the NFL's Vice President for special events since 1977, puts the Super Bowl at the center of the mega-event universe.

The Super Bowl is the most unique of all special events. Extensive studies by host cities, independent organizations and the NFL all try to predict the economic impact the big game will have on a community. They talk to tens of thousands of attendees, local businessmen, corporate planners, media and local fans -- looking to see how they are affected.

These studies have provided irrefutable evidence that a Super Bowl is the most dramatic event in the U.S. Super Bowl patrons are significantly more affluent, spend more and have more spent on them, and influence future business in the community more than attendees of any other event or convention held in the U.S. (Steeg, 1999).

Steeg based his Super Bowl claims on several factors. Most prominent among them from his perspective were: the substantial spending by the NFL and NFL Properties ${ }^{1}$; the number of visitors from outside the community who attended the game and related events; and the ideal fit of the Super Bowl into the convention calendar, which Steeg opined has the capacity for transforming the historically slack month of January into a convention windfall for the host city.

The NFL understands that it is competing for the sports entertainment dollar, and the League believes that stadiums factor prominently into consumer decisions relating to leisure spending. With the completion of stadium construction in Chicago, Green Bay, and Philadelphia, 21 NFL stadiums will have been built or significantly refurbished over the period 
1995 through 2003. This substantial transformation of NFL infrastructure has been accomplished in part through league incentives to include hosting a Super Bowl in some cases and using League shared club seat revenues to help finance stadium construction. ${ }^{2}$ In light of the NFL's strategic success, Steeg's claims warrant further scrutiny.

Scholars not directly connected to the NFL disagree on the economic impact of the Super Bowl. In assessing the impact of Super Bowl XXVIII on the City of Atlanta and the State of Georgia, Jeffrey Humphreys (1994) estimated that the event created 2,736 jobs and had an impact of \$166 million on the Georgia economy. Of the \$166 million, Humphreys estimated direct and indirect economic impact of $\$ 76$ and $\$ 90$ million, respectively. The direct impact was derived from estimating the number of "visitor days" $(306,680)$ and multiplying that statistic by the average estimated per diem expenditures per visitor (\$252). The indirect or induced economic impact was estimated using the Regional Input-Output Multiplier System (RIMS II) model developed by the Bureau of Economic Analysis. A portion of the roughly $\$ 230$ million difference between the estimates for Super Bowls XXXIII and XXVIII is explained by price increases, but most of the difference is attributable to the number of visitors and the daily spending attributable to each of them. In Table 1, a sample of economic impact estimates for selected Super Bowls from 1995 through 2003 are recorded to help provide a context for the impact of the event.

Phil Porter (1999) has provided a far less sanguine appraisal of the Super Bowl's economic impact. Porter used regression analysis to determine that the impact of the event was statistically insignificant, that is not measurably different from zero. After reviewing short-term $\operatorname{data}^{3}$ on sales receipts for several Super Bowls, Porter concluded: 
Investigator bias, data measurement error, changing production relationships, diminishing returns to both scale and variable inputs, and capacity constraints anywhere along the chain of sales relations lead to lower multipliers. Crowding out and price increases by input suppliers in response to higher levels of demand and the tendency of suppliers to lower prices to stimulate sales when demand is weak lead to overestimates of net new sales due to the event. These characteristics alone would suggest that the estimated impact of the megasporting event will be lower than the impact analysis predicts.

Similarly, Baade and Matheson's (1999) examination of twenty-five Super Bowls from 1973 to 1997 found the game associated with an increase in host metropolitan area employment of 537 jobs. Based on simple assumptions regarding the value of a job to a community, they estimate an average economic impact of roughly $\$ 30$ million or roughly one-tenth the figures touted by the NFL. Coates and Humphrey's (2002) cursory look at all post-season play in American professional sports found that hosting the Super Bowl had no statistically significant effect on per capita income in the host city.

From 1995 through 2003, approximately $\$ 6.4$ billion dollars, or an average of $\$ 304$ million, will have been spent to build or substantially refurbish twenty-one NFL stadiums. The public contribution will have been $\$ 4.4$ billion, an average of $\$ 209$ million, or roughly $69 \%$ of the construction costs of these facilities (Peter, 2002). The NFL has offered the Super Bowl as an inducement to convince otherwise reluctant cities that the construction of a new stadium makes economic sense. (It's hard to believe that the NFL would choose to place the Super Bowl in Detroit in January of 2006 except for the presence of the newly constructed Ford Field.) Scholars do not agree on the economic impact of the Super Bowl, and in the next section of the paper, reasons for the disagreement are identified and analyzed.

\section{THEORETICAL ISSUES}

If there is an exaggeration of the benefits induced by a sports mega-event, it occurs for several fundamental reasons. First, the increase in direct spending attributable to the games may 
be a "gross" as opposed to a "net" measure. Some subsidy advocates estimate direct spending by simply summing all receipts associated with the event. The fact that the gross-spending approach fails to account for decreased spending directly attributable to the event represents a major theoretical and practical shortcoming. Surveys on expenditures by those attending the event, complete with a question on place of residence, would appear to be a straightforward way of estimating direct expenditures in a manner that is statistically acceptable. However, while such surveys may well provide acceptable spending estimates for those patronizing the event, they do not reveal changes in spending by residents not attending it. It is conceivable that some local residents or potential visitors may dramatically change their spending given their desire to avoid the congestion at least in the venue's environs. A basic shortcoming of typical economic impact studies, in general, pertains not to information on spending by those included in a direct expenditure survey, but rather to the lack of information on the spending behavior for those who are not.

Robert Baade (1996) has cited the failure to account for the difference between gross and net spending as a chief reason why sports events or teams do not contribute as much to metropolitan economies as boosters claim. However, in the case of a "mega-event," a large proportion of all attendees come from outside the local area, and their spending qualifies as export spending. If the host city's residents who do not attend do not reduce their expenditures within the city, one might contend that direct expenditure by nonresidents who attend events approximates net impact. Unfortunately, this will not be true if some nonresidents, who might have visited the city, decide not to do so because of congestion and high prices during the event's period. In addition, some Super Bowl fans may have already been planning on visiting a 
city but rearrange their schedule to accommodate the sporting event. Even though the economic analyst may attribute this visit to the athletic contest, in fact, this type of time switching does not lead to a net increase in economic activity in the city but simply alters the time period in which the activity takes place.

Recent evidence assessing the economic impact of the Summer Olympics in 2000 in Sydney, Australia indicate this particular "substitution effect" may be substantial even in cases where the event has a clear international character. An Arthur Andersen (2000) survey on hotel activity in Sydney and other capital cities prior to and during the Olympic Games concluded,

As expected, survey results indicate the vast majority of Sydney hotels peaking at near 100\% occupancies during the Games period from September 16-30. This represents an increase of $49 \%$ in occupancy levels relative to the first half of September. In contrast, other capital cities experienced significant demand shortfalls for the same period. For example, occupancies in Melbourne and Brisbane plummeted by $19 \%$ and $17 \%$ in the second half of September relative to the period from 1-15 September. Overall, with the exception of Sydney and Adelaide, all hotel markets in Australia experienced a decline in occupancy in September 2000 relative to September 1999 despite the Olympic Games, as reported in the Hotel Industry Benchmark Survey. Hoteliers indicate that while international demand was strong..., domestic leisure travel traditionally taking place during the September school holiday period was displaced to Sydney for the Olympics.

The Anderson report indicates the importance of the substitution effect, and compels consideration of which, if any, governmental entities should be involved in subsidizing sports mega-events. Sydney's gains may well have come at the expense of other Australian cities, and if the federal government subsidizes the games there must be a rationale for enriching Sydney at the expense of Adelaide and other regional cities.

A second reason economic impact may be exaggerated relates to what economists refer to as the "multiplier," the notion that direct spending increases induce additional rounds of 
spending due to increased incomes that occur as a result of additional spending. If errors are made in assessing direct spending, those errors are compounded in calculating indirect spending through standard multiplier analysis. Furthermore, correct multiplier analysis includes all "leakages" from the circular flow of payments and uses multipliers that are appropriate to the event industry. Leakages may be significant depending on the state of the economy. If the host economy is at or very near full employment, for example, it may be that the labor essential to conducting the event resides in other communities where unemployment or a labor surplus exists. To the extent that this is true, then the indirect spending that constitutes the multiplier effect must be adjusted to reflect this leakage of income and subsequent spending. Siegfried and Zimbalist (2002) note that only $29 \%$ of professional athletes in their study live in the metropolitan area in which their team plays leading to very high levels of leakage from local expenditures on professional sports.

Labor is not the only factor of production that may repatriate income. If hotels experience higher than normal occupancy rates during a mega-event, then the question must be raised about the fraction of increased earnings that remain in the community if the hotel is a nationally owned chain. Finally, most economic impact analyses use expenditure multipliers (rather than income multipliers) to assess the economic impact of an event. The use of expenditure multipliers is unjustified, however, as the important point is not how much business activity is created by an event but rather how the income of local residents is impacted by it. In short, to assess the impact of mega-events, a balance of payments approach should be utilized. That is to say, to what extent does the event give rise to income inflows and outflows that would not occur in its absence? Since the input-output models used in the most sophisticated ex ante 
analyses are based on fixed relationships between inputs and outputs, such models do not account for the subtleties of full employment and capital ownership noted here.

Even to the extent that multipliers are calculated from careful analysis of industry data over an extended period of time, the multipliers are derived from input-output tables based on the normal state of the economy even though the presence of a large temporary tourist attraction such as a the Super Bowl indicates a departure from this normal state. Mega-events such as the Super Bowl are characterized by high utilization rates and increased prices for tourism related industries. While labor may benefit to some extent through increases in hours worked or higher tips, the main recipient of this windfall is likely to be business owners. Expenditures in industries dominated by nationally-owned chains such as large hotels, rental car agencies, and airlines, and to a lesser extent motels, restaurants, and general retailers may rise significantly due to the Super Bowl, but local incomes will not increase substantially. Since the benefits accrue to non-local capital owners leading to higher than normal leakages of income, the money generated from these events is unlikely to recirculate through the economy. Normal multipliers are therefore probably inflated.

As an alternative to estimating the change in expenditures and associated changes in economic activity, those who provide goods and services directly in accommodating the event could be asked how their activity has been altered by the event. In summarizing the efficacy of this technique Davidson (1999) opined:

The biggest problem with this producer approach is that these business managers must be able to estimate how much "extra" spending was caused by the sport event. This requires that each proprietor have a model of what would have happened during that time period had the sport event not taken place. This is an extreme requirement, which severely limits this technique. 
While many potential criticisms of ex ante economic analysis exist, the real question is whether these estimates of the economic impact of the Super Bowl conform to ex post estimates of the economic impact this event exerts on its host cities? In the next section of the paper, the model that is used to develop ex post estimates is detailed.

\section{THE MODEL}

Ex ante models may not provide credible estimates on the economic impact of a megaevent for the reasons cited. An ex post model may be useful in providing a filter through which the promises made by event boosters can be strained. A mega-event's impact is likely to be small relative to the overall economy, and the primary challenge for those doing a post-event audit involves isolating the event's impact. This is not a trivial task, and those who seek insight into the question of economic impact should be cognizant of the challenges and deficiencies common to both ex ante and ex post analyses.

Several approaches are possible in constructing a model to estimate the impact an event has had on a city, and are suggested by past scholarly work. Mills and McDonald (1992) provide an extensive summary of models that have been used to explain metropolitan economic growth. These theories seek to explain increases in economic activity through changes in key economic variables in the short-run (export base and neoclassical models) or the identification of long-term developments that enhance the capacity for growth in metropolitan economies (product cycle, cumulative causation, and disequilibrium dynamic adjustment models).

Our task is not to replicate explanations of metropolitan economic growth, but to use past work to help identify how much of an increase in economic activity in U.S. cities hosting the 
Super Bowl is attributable to the event. To this end we have selected explanatory variables from existing models to predict economic activity in the absence of the game. Estimating the economic impact of the Super Bowl involves comparing the projected level of economic activity without the event to the actual levels of economic activity that occurred in cities that have hosted it. The success of this approach depends on our ability to identify variables that account for the variation in growth in economic activity in host cities.

Given the number and variety of variables found in regional growth models and the inconsistency of findings with regard to coefficient size and significance, criticisms of any single model could logically focus on the problems posed by omitted variables. Any critic, of course, can claim that a particular regression suffers from omitted-variable bias, but it is far more challenging to specify the model so as to remedy the problem. In explaining regional or metropolitan growth patterns, at least some of the omitted variable problem can be addressed through a careful specification of the independent variables. As noted above, representing relevant variables as deviations from city norms, leaves the scholar a more manageable task, namely that of identifying those factors that explain city growth after accounting for the impact of those forces that generally have affected regional or national MSA growth. It is important, for example, to model the fact that relocating a business could occur as a consequence of wages increasing in the MSA under study or a slower rate of wage growth in other MSAs. What matters is not the absolute level of wages in city $i$, but city i's wage relative to that of its competitors.

The purpose of ex ante studies is to provide a measure of the net benefits a project or event is likely to yield. To our knowledge there is no prospective model that has the capacity for 
measuring the net benefits of a project relative to the next best alternative use of those funds. If one assumes that the best use of funds has always occurred prior to a mega-event, then the growth path observed for a city can be construed as optimal. If this optimal growth path, identified by the city's secular growth trend, decreases after the mega-event occurs, then the evidence does not support the hypothesis that a publicly subsidized mega-event put those public monies to the best use.

Our model is designed to predict changes in income attributable to the Super Bowl in host cities 1970 and 2001. The cohort of cities used in the sample includes seventy-three metropolitan areas that represent the largest MSAs in the United States by population over the time period 1970-2001 including every MSA that was among the largest sixty MSAs at some time during that period. While the choice of seventy-three cities is largely arbitrary, the list was expanded to include all metropolitan areas that have hosted the Super Bowl, cities with professional sports franchises (with the exception of Green Bay, WI), and MSAs with professional sports aspirations. The data used are described more fully in Appendix 1. At this point the analysis can be conducted in two ways. Traditionally, researchers such as Coates and Humphreys (2002) and Baade and Matheson (2000) have used fixed effect models on this type of panel data with a dummy variable included for the sporting event(s) and individual dummy variables included for each city in the model to account for regional difference in economic growth. Equation (1) represents the model used to predict changes in income for host cities. 


$$
\Delta Y_{t}^{i}=\beta_{0}+\beta_{1} \Delta Y_{t-1}^{i}+\beta_{2} \frac{Y_{t-1}^{i}}{\sum_{i=1}^{n} Y_{t-1}^{i} / n}+\beta_{3} W_{t}^{i}+\beta_{4} G_{t}^{i}+\beta_{5} O T_{t}^{i}+\beta_{6} P O P_{t}^{i}+\beta_{7} S B_{t}^{i}+\alpha_{i} C^{i}+\gamma_{i} t_{t}^{i}+\varepsilon_{t}^{i}
$$

For each time period $t, Y_{t}^{i}$ is the real personal income and $\Delta Y_{t}^{i}$ is the change in real personal income in the ith metropolitan statistical area (MSA), $n$ is the number of cities in the sample, $W_{t}^{i}$ is the nominal wages in the ith MSA as a percentage of the average for all cities in the sample, $G_{t}{ }^{i}$ is the state and local taxes in the ith MSA as a percentage of the average for all cities in the sample, $P O P_{t}^{i}$ is the log population of the ith city, $S B_{t}^{i}$ is a dummy variable for hosting the Super Bowl, and $\varepsilon_{t}^{i}$ is the stochastic error. $O T_{t}^{i}$ is a dummy variable that represents any significant city-specific economic influences that cannot be explained by other variables in the model including the effects of the oil booms of the 1970s and the subsequent oil bust of the 1980s on oil patch cities of New Orleans and Houston, the effects of Hurricane Andrew on the economy of South Florida, and the economic consequences of the tech boom in Silicon Valley. $C^{i}$ is a vector of dummy variables representing the fixed effect for each city $\mathrm{i}$, and $t$ is a vector of dummy variables representing each year t representing the business cycle. By specifying variables that either represent wages or taxes a percentage of the average, and by using lagged income percentages, problems of endogeneity are largely avoided.

The results of ordinary least-squares regression using equation (1) are shown in Table 2. The coefficient $(0.4058 \%)$ and t-statistic (1.409) on the Super Bowl variable indicate that hosting the Super Bowl is associated with an increase in city personal income growth of $0.4 \%$ but that this figure is not statistically significantly different from zero at a $10 \%$ level.

While the use of fixed effect models is widespread due to their simplicity, they present numerous theoretical and applied difficulties that make their use undesirable when they can be 
avoided. First, the assumptions implicit in the model are quite extreme in that it is assumed the only difference in city growth rates is a fixed percentage in each period. This belies the fact that some cities (such as Detroit or San Jose) are strongly influenced by cyclical industries, and others have experienced growth spurts or slowdowns at varying times in their recent history. To assume that every economic variable affects every city's economic growth in exactly the same way is an absurd albeit often necessary assumption. Next heteroscedasticity is identified as a problem since the variability of the residuals differs widely between cities. For example, the standard deviation of the residuals for the data representing Minneapolis is 0.0056 while the standard deviation of San Jose's residuals is 0.0220 , and a Goldfield-Quandt test for equality of residual variance can be rejected at well beyond a $1 \%$ significance level.

In addition, because the size of the economies of the host cities varies widely, it is difficult to translate the coefficient indicating a $0.4 \%$ increase in economic growth into a convenient dollar figure. Indeed, if the Super Bowl is, say, a $\$ 400$ million event, there is no reason to think that economic growth in each city would be altered by the same amount since percentage-wise such an impact would be different in a small city such as New Orleans compared to a large city such as Los Angeles. Finally, a confidence interval for the Super Bowl variable ranges from a negative range to roughly a $1 \%$ gain in city income, which would correspond to roughly an $\$ 800$ million income in city income for the average host city. So, while a hypothesis of no income gain from hosting the Super Bowl cannot be rejected, neither can the booster's predictions of a $\$ 400$ million gain be rejected.

While some of these issues, as well as potential serial correlation problems, can be dealt with a more advance time-series, panel data regression model, we instead propose a wholly 
different approach. Equation (2) represents the revised model used to predict changes in income for host cities.

$$
\Delta Y_{t}^{i}=\beta_{0}+\beta_{1} \sum_{i=1}^{n} \frac{\Delta Y_{t}^{i}}{n_{t}}+\beta_{2} \Delta Y_{t-1}^{i}+\beta_{3} \frac{Y_{t-1}^{i}}{\sum_{i=1}^{n} Y_{t-1}^{i} / n}+\beta_{4} W_{t}^{i}+\beta_{5} T_{t}^{i}+\beta_{6} T R_{t}^{i}+\beta_{7} O T_{t}^{i}+\alpha S B_{t}^{i}+\varepsilon_{t}^{i}
$$

The variables remain the same as in equation (1) except for the Super Bowl variable. $S B_{t}{ }^{i}$ is now a vector of dummy variables representing the Super Bowl with a separate dummy variable being included for each year a particular city has hosted the game. The major change is that equation (2) was separately estimated for each of the eleven different metropolitan areas that have hosted at least one Super Bowl since 1970 instead of as a panel. Not every variable specified in equation (2) emerged as statistically significant for every city. The decision of whether to include an independent variable known to be a good predictor in general but failing to be statistically significant in a particular city's case is largely an arbitrary one. The inclusion of theoretically valuable variables that are idiosyncratically insignificant will improve some measures of fit such as R-squared but may reduce other measures such as adjusted R-squared or the standard error of the estimate. Since the purpose of equation (2) is to produce predictive rather than explanatory results, variables were included in the regression equation as long as they improved predictive success, and as long as the omission of the variable did not significantly alter the coefficients of the remaining variables. Table 3 presents the regression results for all cities with the combination of variables that minimizes the standard error of the estimate (SEE). Note that Table 3 does not report the regression results for the Super Bowl dummy variables, which are instead reported in Table 4. Finally, Durbin-Watson statistics were calculated for each of the eleven regression equations in Table 3. The results of the Durbin-Watson statistics 
suggested that serial correlation was not a significant problem in any of the eleven regression equations.

As mentioned previously, rather than specifying all the variables that may explain metropolitan growth, we attempted to simplify the task by including only the independent variables that are common to cities in general and the ith MSA in particular. In effect we have devised a structure that attempts to identify the extent to which the deviations from the growth of cities in general $\left(\Sigma \Delta Y_{t}^{i} / n_{t}\right)$ and city i's secular growth $\Delta Y_{t-1}^{i}$, are attributable to deviations in certain costs of production (wages and taxes) or demand-side variables (relative income levels, wages, and taxes).

Relative values of wages and tax burdens are all expected to help explain a city's growth rate in income as it deviates from the sample norm and its own secular growth path. As mentioned above, past research has not produced consistency with respect to the signs and significance of these independent variables. It is not at all clear, for example, whether high levels of relative wages lead to higher or lower income growth. A similar situation exists with relative levels of taxation. As a consequence, a priori expectations are uncertain with regard to the signs of the coefficients. That should not be construed as an absence of theory about key economic relationships. As noted earlier, the models include those variables that previous scholarly work found important.

\section{RESULTS}

The coefficients on the dummy variables for the Super Bowl vector for each model identified in Table 3 are an estimate of the effect of the Super Bowl in each specific year on the 
host city. These coefficients and their corresponding t-stats are shown in Table 4 in the columns labeled "Difference" and "t-stat" along with the real income of each city during the Super Bowl year and the actual observed growth in real income. A predicted personal income growth rate absent the Super Bowl can be calculated by taking the observed growth rate and subtracting out the Super Bowl coefficient. If it is assumed that any difference between actual and predicted income can be accounted for by the presence of the Super Bowl, this method allows for a dollar estimate of the impact of the game on host cities.

For example, the actual personal income growth rate for Phoenix in 1996 was 5.598\% while the coefficient on the 1996 Super Bowl dummy variable was $0.528 \%$ implying a predicted growth rate absent the Super Bowl of only 5.070\% since the model residual for 1996 was 0.000 . Based on Phoenix’s $\$ 71.3$ billion economy, this $0.528 \%$ difference corresponds to an economy that produced income $\$ 377$ million in excess of what would have expected during 1996 if the city had not hosted the championship. The $\$ 377$ million can be interpreted as the contribution of the Super Bowl to the Phoenix economy. In total, the model estimates that the average host city experienced a reduction in personal income of $\$ 133.4$ million relative to the predictions of the model.

The statistics recorded in Table 4 suggest two things worth noting. First, the dollar differences recorded in final column vary substantially with some cities exhibiting income gains well in excess of reasonable booster predictions, and other cities showing a large negative impact. Second, the Super Bowl has an overall negative impact on the host city economy of $\$ 133.4$ million. While this figure is biased downward due to the poor economic performance of Los Angeles in several years, nevertheless this estimate stands in stark contrast to the annual 
gains of $\$ 300$ or $\$ 400$ million projected by the NFL.

The magnitude of the variation of the estimates at first blush appears high. Some host cities (Los Angeles, 1987, and San Diego, 1998) exhibited well over a billion dollars in increased income while others (Los Angeles, 1993 and 1973, and Atlanta, 2000) experienced reductions of billions of dollars. The explanation for this range of estimates is simply that the models do not explain all the variation in estimated income, and, therefore, not all the variation can be attributed to the Super Bowl. In short, there are omitted variables. While the model fit statistics for the individual city regressions display moderately high R-squared numbers, the standard error of the estimate for the typical city is above one percent meaning that one would expected the models to predict actual economic growth for the cities in question within one percentage point less than about two-thirds of the time. For the cities in question, a one percent error translates into a $\$ 200$ to $\$ 500$ million difference for the smallest cities such as Miami and New Orleans and over a \$2 billion difference for Los Angeles, the largest host city. Given the size of these large, diverse economies, the effect of even a large event with hundreds of millions of dollars of potential impact is likely to be obscured by natural, unexplained variations in the economy. Indeed, none of the standardized residuals are statistically significant at the 5\% level. While it is unlikely that the models for any individual city will capture the effects of even a large event, one would expect that across a large number of cities and years, any event that produces a large impact would emerge on average as statistically significant. The t-statistics of the Super Bowl coefficients for the 32 years are normally distributed with a standard deviation of 1. A test on the null hypothesis that the average $\mathrm{t}$-statistic is greater than zero provides a $\mathrm{p}$-value 
of $23.0 \%$. In other words, if the game really had no positive effect on the host cities, then the sample results had only a $23.0 \%$ probability of occurring.

This procedure can be carried one step further. Since the presence of the Super Bowl is not included in making predictions about the economic growth in a particular city, if the Super Bowl has a substantial positive effect on host economies as the boosters suggest, then the appropriate hypothesis test would not be whether the average standardized residual is greater than zero (meaning simply that the event had a positive economic impact) but whether the average standardized residual is greater than some figure that essentially represents a combination of the size of projected impact in comparison to the size of the host city (meaning that the event had a positive economic impact of some designated magnitude.)

Table 5 records various estimates that combine estimates provided by NFL boosters and those predicted by the model. For the purpose of exposition, a $\$ 300$ million Super Bowl (in 2000 dollars) effect is assumed, a figure on the low end of the most recent booster estimates. The model indicates that Phoenix exhibited an increase in income of $\$ 377$ million over that predicted for the city during 1969 if it had not hosted the game. The difference of $\$ 77$ million represents the contribution of the Super Bowl to the Phoenix economy above that of boosters' estimates. While the model predicts that Phoenix should have grown 5.070\% in 1999 compared with 5.598 actual growth, if a booster estimate of $\$ 300$ million is accurate and the model's predictors are uncorrelated to the presence of the Super Bowl, the prediction for Phoenix's economic growth would have been $5.491 \%$. Using these new predicted growth rates that include booster growth projections, new t-statistics can be calculated. A new test on the null hypothesis that the new average t-statistic is greater than zero provides a p-value of $5.00 \%$. In other words, 
had the game had a positive effect of $\$ 300$ million as asserted by the boosters over the thirty-two year period covered by the data, the actual growth rates experienced by the sample would have had only a $5.00 \%$ probability of occurring.

The Super Bowl contribution to predicted growth (and hence the standardized residual) can be adjusted by assuming an economic impact larger or smaller than the $\$ 300$ million figure used in this example. The resulting p-values shown are shown in Table 6.

The predicted economic impact at which the mean t-statistic is zero is $\$ 91.9$ million, a figure roughly one-quarter that of the booster's estimates, and increases in income of $\$ 300$ million and $\$ 392.8$ million can be rejected at the 5\% and $1 \%$ significance levels, respectively. The crowding-out, substitution, and leakages effects can explain the large discrepancy between the observed and actual economic growth and the NFL's claims. While the Super Bowl undoubtedly attracts large numbers of wealthy, out-of-town visitors, the "crowding-out" effect due to perceptions relating to limited hotel rooms and high hotel prices, rowdy behavior of football fans, and peak use of public goods such as highways and sidewalks are substantial. Furthermore, the net effect on the host economy of the conventions or other tourists who went elsewhere would depend on the details relating to the spending patterns of football fans versus those of the lost visitors and convention attendees. The spending of residents of the host city may be altered to the detriment of the city's economy as local citizens may not frequent areas in which the event occurs or the fans stay. In addition, although hotel room rates in host cities invariably increase substantially during the Super Bowl weekend, the to the extent that these hotels are nationally owned chains, the higher prices benefit corporate stockholders, not local residents and are not reflected in the personal income levels of the metropolitan area. 


\section{CONCLUSIONS AND POLICY IMPLICATIONS}

The National Football League and other sports leagues have used the promise of an all star game or league championship as an incentive for host cities to construct new stadiums or arenas, and with few exceptions, at considerable public expense. Recent NFL studies have estimated that Super Bowls increase economic activity by hundreds of millions of dollars in host cities. Our analysis fails to support NFL claims. Our detailed regression analysis revealed that over the period 1970 to 2001, on average Super Bowls created $\$ 92$ million in income gains for host cities, a figure roughly one-quarter that of recent NFL claims. While this figure, like any econometric estimate, is subject to some degree of uncertainty, statistical analysis reveals that, on average the Super Bowl could not have contributed, by a reasonable standard of statistical significance, more than $\$ 300$ million to host economies.

Cities would be wise to view with caution Super Bowl economic impact estimates provided by the NFL. It would appear that padding is an essential element of the game both on and off the field. 


\section{REFERENCES}

Arthur Andersen, Hospitality and Leisure Services. "The Sydney Olympic Performance Survey: The Sydney Olympic Games on the Australian Hotel Industry." Mimeograph, 2000, 1-7.

Baade, R. "Professional Sports as a Catalyst for Metropolitan Economic Development." Journal of Urban Affairs, 18(1), 1996, 1-17.

Baade, R. and Matheson, V. "An Assessment of the Economic Impact of the American Football Championship, the Super Bowl, on Host Communities." Reflets et Perspectives, 39(2-3), 2000, 35-46.

Coates, D. and Humphreys, B. "The Economic Impact of Post-Season Play in

Professional Sports.” Journal of Sports Economics, 3(3), 2002, 291-299.

Davidson, L. "Choice of a Proper Methodology to Measure Quantitative and Qualitative Effects of the Impact of Sport." in The Economic Impact of Sports Events, ed. Claude Jeanrenaud. Neuchatel, Switzerland: Centre International d'Etude du Sport, 1999, 9-28.

Humphries, J. “The Economic Impact of Hosting Super Bowl XXVIII on Georgia." Georgia Business and Economic Conditions, May-June 1994, 18-21.

Mills, E. and McDonald, J. eds. Sources of Metropolitan Growth, New Brunswick, N.J.: Center for Urban Policy Research, 1992.

National Football League. "Eagles, Steelers Make Plans for New Stadiums.” NFL Report, 58(3), 1999.

National Football League. "Super Bowl XXXII Generates \$396 Million for South Florida.” NFL Report, 58(7), 1999(b).

Peter, J. "Building NFL Fortunes.” The Times-Picayune, Section C, p. 1, July 14, 2002.

Porter, P. "Mega-Sports Events as Municipal Investments: A Critique of Impact Analysis." in Fizel, J., Gustafson, E., and Hadley, L., eds. Sports Economics: Current Research. New York: Praeger Press, 1999.

Seigfried, J. and Zimbalist, A. "A Note on the Local Economic Impact of Sports Expenditures." Journal of Sports Economics, 3:4, 2002, 361-366.

Steeg, J., “Inquiring Minds Should Know.” Fox Sports Biz.com, November 9, 1999. 


\section{FOOTNOTES}

*The is a revision of a paper presented at the Western Economic Association International $79^{\text {th }}$ annual conference, Vancouver, July 2, 2004, in a session organized by Brad Humphreys, University of Illinois. The authors are grateful for the comments and suggestions made by session participants and anonymous referees.

1. Steeg claimed that the NFL and NFL Properties spend a combined $\$ 43$ million on Super Bowl XXXIV, for example.

2. At the March 1999 NFL meetings, the teams agreed to allow teams to qualify for up-front loans in an amount equal to $34 \%$ to $50 \%$ of the private contributions for stadium projects. The specific amount would be determined by the size of the project and the market the stadium would serve.

3. Porter's use of monthly sales receipts is important. If the researcher can compress the time period, then it is less likely that the impact of the event will be obscured by the large, diverse economy within which it took place. The use of annual data has the potential to mask an event's impact through the sheer weight of activity that occurs in large economies over the course of a year unless steps are taken to isolate the event.

A full description of the data used for analysis is available from the authors upon request. 
TABLE 1

Economic Impact Estimates Provided by Boosters for Selected Super Bowls Between 1995 and 2003

\begin{tabular}{cccc}
\hline Year & Author & City & $\begin{array}{c}\text { Estimate in millions of \$ and } \\
\text { (in millions of 2000 \$) }\end{array}$ \\
\hline 1995 & $\begin{array}{c}\text { NFL and Kathleen Davis, Sports } \\
\text { Management Research Institute }\end{array}$ & Miami & $\$ 365$ \\
1998 & PriceWaterhouseCoopers & San Diego & $(\$ 412.4)$ \\
& & & $\$ 295$ \\
1999 & NFL and Kathleen Davis, Sports & Miami & $(\$ 311.7)$ \\
& Management Research Institute & & $\$ 393$ \\
2000 & Jason Ader, & Atlanta & $(\$ 406.2)$ \\
& Bear Stearns & & $(\$ 410)$ \\
2000 & Jeffrey Humphreys, & Atlanta & $\$ 292$ \\
& Georgia State University & & $(\$ 292)$ \\
& Super Bowl Host Committee & San Diego & $\$ 375$ \\
& & & $(\$ 356.8)$ \\
\hline
\end{tabular}


TABLE 2

\section{Regression results for Fixed Effect Model}

Model Summary

$\begin{array}{crrrl} & & \text { Adjusted } & \text { Std. Error of } & \\ \mathrm{R} & \text { R Square } & \text { R Square } & \text { the Estimate } & \text { Durbin-Watson } \\ 0.87428 & 0.7644 & 0.7509 & 0.01474 & 2.03963\end{array}$

ANOVA

\begin{tabular}{lrrrrrr} 
& Sum of Squares & \multicolumn{1}{l}{ Df } & Mean Square & F & Sig. \\
Regression & 1.42920 & 116 & 0.01232 & 56.7116 & & 0 \\
Residual & 0.44055 & 2028 & 0.00022 & & & \\
Total & 1.86965 & 2144 & & & &
\end{tabular}

Dependent Variable: $\% \Delta$ Income

Independent Variables

Coefficients

t-stat Significance

(Constant)

B

Std. Error

$\% \Delta$ Income (t-1)

$\begin{array}{ll}0.3827 & 0.0493\end{array}$

Log Population

$\begin{array}{ll}0.4432 & 0.0207\end{array}$

7.764

0.0000

$\begin{array}{lll}0.0207 & 21.366-0.0000 \\ 0.0074 & -7.006 & 0.0000\end{array}$

Income as \% of sample average ( $\mathrm{t}-1)$

$-0.0519$

0.0074

0.0000

$-0.0343$

0.0077

$-4.452$

0.0000

$\begin{array}{llll}-0.0018 & 0.006 & -0.291 & 0.7714\end{array}$

Wages as \% of sample average (t-1)

$-0.0335$

0.0078

$-4.287$

0.0000

Hurricane Andrew

$-0.0399$

$0.0107 \quad-3.736$

0.0002

Hurricane Andrew recovery

0.0582

0.0088

6.607

0.0000

Tech Boom 1

$\begin{array}{ll}0.0478 & 0.0089\end{array}$

5.370

0.0000

Tech Boom 2

$\begin{array}{ll}0.0804 & 0.0090\end{array}$

8.937

0.0000

$-0.0978$

0.0093

$-10.497$

0.0000

Super Bowl

0.0041

0.0029

1.409

$\mathbf{0 . 1 5 9 0}$

Oil Boom 1

0.0099

2.505

0.0123

$\begin{array}{ll}0.0153 & 0.0035\end{array}$

4.400

0.0000

$\begin{array}{lll}-0.0268 & 0.0032 & -8.483\end{array}$

0.0000

Oil Bust

$-0.0067$

0.0054

$-1.243$

0.2141

Year 2001

$\begin{array}{lll}-0.0112 & 0.0025 & -4.479\end{array}$

0.0000 ...

Fixed effects for individual cities/years shown for Albany MSA and the year 2001 but are excluded for remaining years and cities. Full results available from the authors upon request. 
TABLE 3: Regression results for equation (2) (t-stats in parentheses).

Coefficients for Super Bowl dummy variables are omitted from results and instead shown in Table 4.

\begin{tabular}{|c|c|c|c|c|c|c|c|c|c|c|c|c|}
\hline MSA & Cons. & $\begin{array}{c}\text { Average } \\
\mathbf{Y}_{\mathrm{t}} \\
\end{array}$ & $\mathbf{Y}_{\mathrm{t}-1}$ & $Y_{t-2}$ & $Y_{t-3}$ & $\begin{array}{c}\text { Income } \\
\text { as } \% \\
\end{array}$ & $\begin{array}{c}\text { Wages } \\
\text { as } \% \\
\end{array}$ & $\begin{array}{l}\text { Taxes } \\
\text { as } \% \\
\end{array}$ & $\begin{array}{c}\text { Log } \\
\text { Population } \\
\end{array}$ & Time & Other & Fit \\
\hline Atlanta & $\begin{array}{l}-15.85 \\
(-3.30)\end{array}$ & $\begin{array}{l}1.092 \\
(8.02)\end{array}$ & $\begin{array}{l}.232 \\
(2.44)\end{array}$ & $\begin{array}{l}.090 \\
(0.92)\end{array}$ & $\begin{array}{l}.034 \\
(034)\end{array}$ & $\begin{array}{l}-.616 \\
(-2.74)\end{array}$ & - & $\begin{array}{l}-.395 \\
(-2.93)\end{array}$ & $\begin{array}{l}-.698 \\
(-2.61)\end{array}$ & $\begin{array}{l}.0107 \\
(3.124\end{array}$ & - & $\begin{array}{l}\text { Adj. } \mathrm{R}^{2}=.9027 \\
\mathrm{SEE}=0.9729 \%\end{array}$ \\
\hline Detroit & $\begin{array}{l}.024 \\
(3.79)\end{array}$ & $\begin{array}{l}1.166 \\
(8.21)\end{array}$ & $\begin{array}{l}.432 \\
(5.17)\end{array}$ & - & - & $\begin{array}{l}-.815 \\
(-4.76)\end{array}$ & $\begin{array}{c}-.107 \\
(-0.70)\end{array}$ & $\begin{array}{l}-.164 \\
(-1.61)\end{array}$ & $\begin{array}{l}1.354 \\
(2.86)\end{array}$ & $\begin{array}{l}-.0041 \\
(-3.31)\end{array}$ & - & $\begin{array}{l}\text { Adj. } \mathrm{R}^{2}=.9314 \\
\mathrm{SEE}=0.9314 \%\end{array}$ \\
\hline Houston & $\begin{array}{l}.192 \\
(2.37)\end{array}$ & $\begin{array}{l}.737 \\
(3.13)\end{array}$ & $\begin{array}{l}.395 \\
(2.35)\end{array}$ & - & - & $\begin{array}{l}-.185 \\
(-2.27)\end{array}$ & - & - & - & - & $\begin{array}{l}.0402 \\
(2.84) \\
-.0416 \\
(-2.66)\end{array}$ & $\begin{array}{l}\text { Adj. } \mathrm{R}^{2}=.5186 \\
\mathrm{SEE}=2.3443 \%\end{array}$ \\
\hline Los Angeles & $\begin{array}{l}-1.902 \\
(-1.69)\end{array}$ & $\begin{array}{l}.968 \\
(7.37)\end{array}$ & $\begin{array}{l}.218 \\
(2.11)\end{array}$ & - & - & - & - & - & $\begin{array}{l}-.621 \\
(-1.92)\end{array}$ & $\begin{array}{l}.0031 \\
(1.90)\end{array}$ & - & $\begin{array}{l}\text { Adj. } R^{2}=.7308 \\
S E E=1.3386 \%\end{array}$ \\
\hline Miami & $\begin{array}{l}12.14 \\
(2.42)\end{array}$ & $\begin{array}{l}.904 \\
(5.92)\end{array}$ & $\begin{array}{l}.260 \\
(2.14)\end{array}$ & - & - & $\begin{array}{l}-.671 \\
(-2.35)\end{array}$ & $\begin{array}{l}.430 \\
(2.32)\end{array}$ & - & - & $\begin{array}{l}-.0060 \\
(-2.45)\end{array}$ & $\begin{array}{l}-.0805 \\
(-5.11) \\
.0865 \\
(3.47)\end{array}$ & $\begin{array}{l}\text { Adj. } R^{2}=.8461 \\
S E E=1.4108 \%\end{array}$ \\
\hline Mpls. & $\begin{array}{l}-.869 \\
(-3.64)\end{array}$ & $\begin{array}{l}1.042 \\
(18.12)\end{array}$ & $\begin{array}{l}.058 \\
(1.12)\end{array}$ & - & - & $\begin{array}{l}-.269 \\
(-2.70)\end{array}$ & $\begin{array}{l}.212 \\
(2.25)\end{array}$ & - & $\begin{array}{l}.144 \\
(4.22)\end{array}$ & - & - & $\begin{array}{l}\text { Adj. } R^{2}=.9521 \\
\mathrm{SEE}=0.5115 \%\end{array}$ \\
\hline New Orleans & $\begin{array}{l}.320 \\
(2.52)\end{array}$ & $\begin{array}{l}.601 \\
(3.78)\end{array}$ & - & - & - & $\begin{array}{l}-.179 \\
(-1.96)\end{array}$ & - & $\begin{array}{l}-.191 \\
(-2.51)\end{array}$ & - & - & $\begin{array}{l}.0153 \\
(1.79)\end{array}$ & $\begin{array}{l}\text { Adj. } \mathrm{R}^{2}=.5768 \\
\mathrm{SEE}=1.3397 \%\end{array}$ \\
\hline & & & & & & & & & & & $\begin{array}{l}-.0213 \\
(-2.33)\end{array}$ & \\
\hline Phoenix & $\begin{array}{l}-33.19 \\
(-2.10)\end{array}$ & $\begin{array}{l}1.310 \\
(8.50)\end{array}$ & $\begin{array}{l}.516 \\
(5.942\end{array}$ & $\begin{array}{l}.327 \\
(2.86)\end{array}$ & - & $\begin{array}{l}-1.104 \\
(-3.39)\end{array}$ & $\begin{array}{l}.427 \\
(3.11)\end{array}$ & $\begin{array}{l}-.187 \\
(-2.54)\end{array}$ & $\begin{array}{l}-1.597 \\
(2.71)\end{array}$ & $\begin{array}{l}.0221 \\
(2.27)\end{array}$ & - & $\begin{array}{l}\text { Adj. } \mathrm{R}^{2}=.8635 \\
\mathrm{SEE}=1.3188 \%\end{array}$ \\
\hline San Diego & $\begin{array}{l}1.036 \\
(3.37)\end{array}$ & $\begin{array}{l}1.023 \\
(8.56)\end{array}$ & $\begin{array}{l}.240 \\
(2.87)\end{array}$ & - & - & - & $\begin{array}{l}-.227 \\
(-2.69)\end{array}$ & - & $\begin{array}{l}-.127 \\
(-3.39)\end{array}$ & - & - & $\begin{array}{l}\text { Adj. } \mathrm{R}^{2}=.8360 \\
\mathrm{SEE}=1.1329 \%\end{array}$ \\
\hline San Jose & $\begin{array}{l}-11.54 \\
(-4.72)\end{array}$ & $\begin{array}{l}1.138 \\
(8.22)\end{array}$ & - & -. & - & $\begin{array}{l}-.362 \\
(-7.09)\end{array}$ & $\begin{array}{l}-.643 \\
(-4.68)\end{array}$ & $\begin{array}{l}.150 \\
(2.25)\end{array}$ & - & $\begin{array}{l}.0063 \\
(4.88)\end{array}$ & $\begin{array}{l}.0900 \\
(5.44)\end{array}$ & $\begin{array}{l}\text { Adj. } \mathrm{R}^{2}=.8919 \\
\mathrm{SEE}=1.5260 \%\end{array}$ \\
\hline & & & & & & & & & & & $\begin{array}{l}.1815 \\
(10.46)\end{array}$ & \\
\hline Tampa & $\begin{array}{l}-9.215 \\
(-1.78)\end{array}$ & $\begin{array}{l}0.909 \\
(5.44)\end{array}$ & $\begin{array}{l}.311 \\
(2.64)\end{array}$ & - & - & $\begin{array}{l}-.529 \\
(-1.68)\end{array}$ & $\begin{array}{l}-.309 \\
(-1.97)\end{array}$ & $\begin{array}{l}-.392 \\
(-2.00)\end{array}$ & $\begin{array}{l}-.815 \\
(-1.96)\end{array}$ & $\begin{array}{l}.0077 \\
(1.94)\end{array}$ & - & $\begin{array}{l}\text { Adj. } R^{2}=.7303 \\
S E E=1.3746 \%\end{array}$ \\
\hline
\end{tabular}



TABLE 4

\section{Super Bowl Contribution to Local Economies}

\begin{tabular}{|c|c|c|c|c|c|c|c|}
\hline Year & $\begin{array}{c}\text { Real Income } \\
\text { (2000 \$) }\end{array}$ & $\begin{array}{c}\text { Pred. } \\
\text { Growth }\end{array}$ & $\begin{array}{l}\text { Actual } \\
\text { Growth }\end{array}$ & $\begin{array}{c}\text { Difference } \\
\text { (S.B. coeff.) }\end{array}$ & t-stat & & Income $+/-$ \\
\hline 1970 New Orleans & $\$ 18,748,279$ & $1.776 \%$ & $1.860 \%$ & $0.084 \%$ & 0.061 & $\$$ & 15,796 \\
\hline 1971 Miami & $\$ 27,239,344$ & $7.182 \%$ & $5.332 \%$ & $-1.850 \%$ & -1.020 & $\$$ & $(503,947)$ \\
\hline 1972 New Orleans & $\$ 20,493,238$ & $4.281 \%$ & $5.855 \%$ & $1.574 \%$ & 1.052 & $\$$ & 322,620 \\
\hline 1973 Los Angeles & $\$ 166,013,025$ & $4.911 \%$ & $1.941 \%$ & $-2.970 \%$ & -2.006 & $\$$ & $(4,929,805)$ \\
\hline 1974 Houston & $\$ 47,263,119$ & $8.079 \%$ & $7.471 \%$ & $-0.608 \%$ & -0.221 & $\$$ & $(287,386)$ \\
\hline 1975 New Orleans & $\$ 22,191,318$ & $2.549 \%$ & $2.447 \%$ & $02 \%$ & -0.066 & $\$$ & $(22,664)$ \\
\hline 1976 Miami & $\$ 31,966,339$ & $3.434 \%$ & $2.083 \%$ & $51 \%$ & -0.746 & $\$$ & $(431,897)$ \\
\hline 1977 Los Angeles & $\$ 178,631,079$ & $4.810 \%$ & $3.983 \%$ & $7 \%$ & -0.558 & $\$$ & $(1,477,256)$ \\
\hline 1978 New Orleans & $\$ 26,342,160$ & $3.520 \%$ & $5.852 \%$ & $32 \%$ & & $\$$ & 614,179 \\
\hline 1979 Miami & $\$ 35,677,084$ & $2.890 \%$ & $67 \%$ & $3 \%$ & & $\$$ & 390) \\
\hline 1980 Los Angeles & $\$ 190,215,123$ & $-0.688 \%$ & $-1.584 \%$ & -0.8 & -0.6 & $\$$ & $(1,704,380)$ \\
\hline 1981 New Orleans & $\$ 28,3$ & $2.316 \%$ & $9 \%$ & $3 \%$ & & $\$$ & \\
\hline 1982 Detroit & $\$ 95,268,030$ & $-2.905 \%$ & $-4.366 \%$ & -1.4 & -1.282 & $\$$ & $(1,39$ \\
\hline 1983 Los Angeles & $\$ 198$ & 2.6 & $4 \%$ & $4 \%$ & & $\$$ & 1,61 \\
\hline 1984 Tampa & $\$ 40,86$ & $7.323 \%$ & $7.707 \%$ & $3 \%$ & 0.219 & $\$$ & 553 \\
\hline 1985 San Jose & $\$ 46,22$ & 4.3 & 3.0 & $2 \%$ & & $\$$ & 343) \\
\hline 1986 New Orleans & $\$ 29,49$ & $-0.311 \%$ & $-1.166 \%$ & -0.8 & -0.550 & $\$$ & 203) \\
\hline 1987 Los Angeles & $\$ 240,76$ & $2.230 \%$ & $40 \%$ & $0 \%$ & 1.523 & $\$$ & 5,32 \\
\hline 1988 San Diego & $\$ 66,440,307$ & $4.189 \%$ & $5.394 \%$ & $1.206 \%$ & 0.990 & $\$$ & 941 \\
\hline 1989 Miami & $\$ 47,494,929$ & $1.868 \%$ & $4.078 \%$ & $10 \%$ & 1.497 & $\$$ & 1,049 \\
\hline 1990 New Orleans & $\$ 29,669,092$ & $1.247 \%$ & $1.600 \%$ & $0.353 \%$ & 0.244 & $\$$ & 677 \\
\hline 1991 Tampa & $\$ 51,242,892$ & $-0.896 \%$ & $-1.330 \%$ & $34 \%$ & -0.270 & $\$$ & $(222,309)$ \\
\hline 1992 Minneapolis & $\$ 79,702,545$ & $3.413 \%$ & $4.050 \%$ & $0.637 \%$ & 1.101 & $\$$ & 508,062 \\
\hline 1993 Los Angeles & $\$ 243,170,360$ & $-0.256 \%$ & $-2.506 \%$ & $-2.250 \%$ & -1.583 & $\$$ & $(5,471,429)$ \\
\hline 1994 Atlanta & $\$ 96,197,361$ & $4.644 \%$ & $5.381 \%$ & $0.737 \%$ & 0.624 & $\$$ & 709,310 \\
\hline 1995 Miami & $\$ 50,355,627$ & $0.344 \%$ & $3.139 \%$ & $2.795 \%$ & 1.792 & $\$$ & $1,407,511$ \\
\hline 1996 Phoenix & $\$ 71,299,199$ & $5.070 \%$ & $5.598 \%$ & $0.528 \%$ & 0.340 & $\$$ & 376,529 \\
\hline 1997 New Orleans & $\$ 33,755,733$ & $2.137 \%$ & $2.768 \%$ & $0.631 \%$ & 0.450 & $\$$ & 213,078 \\
\hline 1998 San Diego & $\$ 82,567,615$ & $6.479 \%$ & $8.457 \%$ & $1.977 \%$ & 1.601 & $\$$ & $1,632,475$ \\
\hline 1999 Miami & $\$ 57,068,632$ & $1.458 \%$ & $3.525 \%$ & $2.068 \%$ & 1.321 & $\$$ & $1,179,931$ \\
\hline 2000 Atlanta & $\$ 139,018,879$ & $7.578 \%$ & $6.368 \%$ & $-1.210 \%$ & -0.968 & $\$$ & $(1,681,953)$ \\
\hline 2001 Tampa & $\$ 69,855,497$ & $3.551 \%$ & $\underline{1.066 \%}$ & $-2.485 \%$ & $\underline{-1.093}$. & $\$$ & $(1,736,037)$ \\
\hline Average & & $3.098 \%$ & $3.206 \%$ & $0.108 \%$ & 0.132 & 8 & $(133,398)$ \\
\hline
\end{tabular}


TABLE 5

Super Bowl Contribution to Local Economies assuming a $\$ 300$ million Super Bowl boost.

\begin{tabular}{|c|c|c|c|c|c|c|c|c|}
\hline Year & City & Income & $\begin{array}{l}\text { Super Bowl } \\
\text { Growth }\end{array}$ & $\begin{array}{l}\text { Model Pred. } \\
\text { Growth }\end{array}$ & $\begin{array}{l}\text { Total Pred. } \\
\text { Growth }\end{array}$ & $\begin{array}{l}\text { Actual } \\
\text { Growth }\end{array}$ & Difference & t-stat \\
\hline 1970 & New Orleans & \$ $18,748,279$ & $1.600 \%$ & $1.776 \%$ & $3.376 \%$ & $1.860 \%$ & $-1.516 \%$ & -1.096 \\
\hline 1971 & Miami & \$ $27,239,344$ & $1.101 \%$ & $7.182 \%$ & $8.283 \%$ & $5.332 \%$ & $-2.951 \%$ & -1.627 \\
\hline 1972 & New Orleans & $\$ 20,493,238$ & $1.464 \%$ & $4.281 \%$ & $5.745 \%$ & $5.855 \%$ & $0.110 \%$ & 0.074 \\
\hline 1973 & Los Angeles & $\$ 166,013,025$ & $0.181 \%$ & $4.911 \%$ & $5.092 \%$ & $1.941 \%$ & $-3.150 \%$ & -2.128 \\
\hline 1974 & Houston & $\$ 47,263,119$ & $0.635 \%$ & $8.079 \%$ & $8.713 \%$ & $7.471 \%$ & $-1.243 \%$ & -0.451 \\
\hline 1975 & New Orlear & $\$ 22,191,318$ & $.352 \%$ & $2.549 \%$ & $3.901 \%$ & $2.447 \%$ & $154 \%$ & -0.937 \\
\hline 1976 & Miami & $\$ 31,966,3$ & & & & & & \\
\hline 1977 & Los Angeles & $\$ 178,6$ & & & & & & 571 \\
\hline 1978 & New Orl & $\$ 26,3$ & & & & & & \\
\hline 1979 & Miami & $\$ 35,677,084$ & $841 \%$ & $2.890 \%$ & $3.731 \%$ & $2.567 \%$ & $\%$ & -0.757 \\
\hline 1980 & Los Angeles & $\$ 190,215,123$ & $0.158 \%$ & $-0.688 \%$ & $-0.531 \%$ & $-1.584 \%$ & $-1.054 \%$ & -0.708 \\
\hline 1981 & New Orleans & $\$ 28,341,623$ & $1.059 \%$ & $2.316 \%$ & $3.374 \%$ & $4.089 \%$ & $0.714 \%$ & 0.467 \\
\hline 1982 & Detroit & $\$ 95,268,030$ & $315 \%$ & $-2.905 \%$ & $-2.590 \%$ & $-4.366 \%$ & $-1.777 \%$ & -1.558 \\
\hline 1983 & Los Angeles & $\$ 198,91$ & & $2.600 \%$ & $2.751 \%$ & 14\% & & 0.477 \\
\hline 1984 & Tampa & $\$ 40,8$ & & & & $07 \%$ & & -0.201 \\
\hline 19 & San Jose & $\$ 46,2$ & & & & & & 160 \\
\hline 1986 & New Orle & \$ 29,4 & & & & & & -1.205 \\
\hline 1987 & Los Ang & $\$ 240,7$ & & & & & & .437 \\
\hline 1988 & San Dieg & $\$ 66,4$ & & $89 \%$ & $4.640 \%$ & $5.394 \%$ & & 0.619 \\
\hline 1989 & Miami & \$ 47,494,929 & $632 \%$ & $868 \%$ & $2.499 \%$ & $4.078 \%$ & $1.579 \%$ & 1.069 \\
\hline 1990 & New Orleans & $\$ 29,669,092$ & $011 \%$ & $247 \%$ & $.258 \%$ & $1.600 \%$ & $-0.658 \%$ & -0.455 \\
\hline 1991 & Tampa & $\$ 51,242,892$ & $585 \%$ & $-0.896 \%$ & $-0.311 \%$ & $-1.330 \%$ & -1.019 & -0.634 \\
\hline 1992 & Minneapolis & $\$ 79,702,545$ & $376 \%$ & $3.413 \%$ & $3.789 \%$ & $4.050 \%$ & $0.261 \%$ & 0.451 \\
\hline 1993 & Los Angeles & $\$ 243,17$ & & & & $-2.506 \%$ & & -1.670 \\
\hline & & & & & & & & 0.360 \\
\hline 1995 & Miami & $\$ 50,3$ & & & & & & 1.410 \\
\hline 1996 & Phoenix & $\$ 71,2$ & & & & & & 0.069 \\
\hline 1997 & New Orleans & $\$ 33,75$ & & & $.026 \%$ & $2.768 \%$ & $-0.258 \%$ & -0.183 \\
\hline 1998 & San Diego & $\$ 82,56$ & & $.479 \%$ & & $8.457 \%$ & & 1.306 \\
\hline 1999 & Miami & $\$ 57,068,63$ & $526 \%$ & $1.458 \%$ & $1.983 \%$ & $3.525 \%$ & $1.542 \%$ & 0.985 \\
\hline 2000 & Atlanta & $\$ 139,018,879$ & $216 \%$ & $7.578 \%$ & $7.794 \%$ & $6.368 \%$ & $-1.426 \%$ & -1.140 \\
\hline \multirow{2}{*}{$\underline{2001}$} & Tampa & $\$ 69,855,497$ & $\underline{0.429 \%}$ & $\underline{3.551 \%}$ & $\underline{3.980 \%}$ & $1.066 \%$ & $-2.915 \%$ & -1.282 \\
\hline & Average & & & & & & & \\
\hline
\end{tabular}


TABLE 6

Probabilities for Various Levels of Economic Impact Induced by the Super Bowl

\begin{tabular}{cc}
\hline Economic Impact & $\begin{array}{c}\text { Probability of such an impact or greater } \\
\text { having occurred }\end{array}$ \\
\hline \$400 million & $0.87 \%$ \\
\$392.8 million & $1.00 \%$ \\
\$300 million & $5.00 \%$ \\
\$252.7 million & $10.00 \%$ \\
\$200 million & $19.28 \%$ \\
\$100 million & $47.40 \%$ \\
\$91.9 million & $50.00 \%$ \\
\$0 & $77.00 \%$ \\
Negative & $23.00 \%$ \\
\hline
\end{tabular}




\section{APPENDIX}

Table A1: Cities and years used to estimate model in Tables 2, 3

\begin{tabular}{|c|c|c|c|c|c|}
\hline MSA Name & $\begin{array}{c}1969 \\
\text { Population }\end{array}$ & $\begin{array}{l}1969 \\
\text { Rank }\end{array}$ & $\begin{array}{c}2000 \\
\text { Population }\end{array}$ & $\begin{array}{l}2000 \\
\text { Rank }\end{array}$ & Wage Data availability \\
\hline Akron, $\mathrm{OH}$ & 676,214 & 59 & 695,781 & 77 & $1972-2000$ \\
\hline Albany, NY & 797,010 & 50 & 876,129 & 68 & $1969-2000$ \\
\hline Atlanta, GA & $1,742,220$ & 16 & $4,144,774$ & 9 & $1972-2000$ \\
\hline Austin, TX & 382,835 & 88 & $1,263,559$ & 47 & $1972-2000$ \\
\hline Baltimore, MD & $2,072,804$ & 12 & $2,557,003$ & 18 & $1972-2000$ \\
\hline Bergen, NJ & $1,354,671$ & 26 & $1,374,345$ & 44 & $\begin{array}{r}1969-2000 \\
\text { (State data 1969-2000) }\end{array}$ \\
\hline Birmingham, AL & 718,286 & 54 & 922,820 & 67 & $\begin{array}{r}1970-2000 \\
\text { (State data } 1970-1971)\end{array}$ \\
\hline Boston, MA & $5,182,413$ & 4 & $6,067,510$ & 4 & $1972-2000$ \\
\hline Buffalo, NY & $1,344,024$ & 27 & $1,168,552$ & 52 & $\begin{array}{r}1969-2000 \\
\text { (Average of cities) }\end{array}$ \\
\hline Charlotte, NC & 819,691 & 49 & $1,508,050$ & 42 & $1972-2000$ \\
\hline Chicago, IL & $7,041,834$ & 2 & $8,289,936$ & 3 & $1972-2000$ \\
\hline Cincinnati, $\mathrm{OH}$ & $1,431,316$ & 21 & $1,649,228$ & 34 & $1969-2000$ \\
\hline Cleveland, $\mathrm{OH}$ & $2,402,527$ & 11 & $2,250,096$ & 24 & $1969-2000$ \\
\hline Columbus, $\mathrm{OH}$ & $1,104,257$ & 33 & $1,544,794$ & 41 & $1972-2000$ \\
\hline Dallas, TX & $1,576,589$ & 18 & $3,541,099$ & 10 & $1972-2000$ \\
\hline Dayton, $\mathrm{OH}$ & 963,574 & 42 & 950,177 & 65 & $1969-2000$ \\
\hline Denver, CO & $1,089,416$ & 34 & $2,120,775$ & 25 & $1977-2000$ \\
\hline Detroit, MI & $4,476,558$ & 6 & $4,444,693$ & 7 & $1976-2000$ \\
\hline Fort Lauderdale, FL & 595,651 & 70 & $1,632,071$ & 36 & $\begin{array}{r}1969-2000 \\
\text { (State data } 1988-2000)\end{array}$ \\
\hline Fort Worth, TX & 766,903 & 51 & $1,713,122$ & 30 & $\begin{array}{r}1976-2000 \\
\text { (State data 1976-1983) }\end{array}$ \\
\hline Fresno, CA & 449,383 & 79 & 925,883 & 66 & $\begin{array}{r}1969-2000 \\
\text { (State data 1982-1987) }\end{array}$ \\
\hline Grand Rapids, MI & 753,936 & 52 & $1,091,986$ & 59 & $1976-2000$ \\
\hline Greensboro, NC & 829,797 & 48 & $1,255,125$ & 48 & $1972-2000$ \\
\hline Greenville, SC & 605,084 & 67 & 965,407 & 63 & $\begin{array}{r}1969-2000 \\
\text { (State data 1969) }\end{array}$ \\
\hline Hartford, CT & $1,021,033$ & 39 & $1,150,619$ & 53 & $1969-2000$ \\
\hline Honolulu, HI & 603,438 & 68 & 875,670 & 69 & $1972-2000$ \\
\hline Houston, TX & $1,872,148$ & 15 & $4,199,526$ & 8 & $1972-2000$ \\
\hline Indianapolis, IN & $1,229,904$ & 30 & $1,612,538$ & 37 & $1989-2000$ \\
\hline Jacksonville, FL & 610,471 & 66 & $1,103,911$ & 57 & $\begin{array}{r}1972-2000 \\
\text { (State data 1988-2000) }\end{array}$ \\
\hline Kansas City, MO & $\begin{array}{r}1,365,715 \\
297628\end{array}$ & $\begin{array}{r}25 \\
116\end{array}$ & $\begin{array}{l}1,781,537 \\
1582679\end{array}$ & 28 & $\begin{array}{r}1972-2000 \\
1972-2000\end{array}$ \\
\hline
\end{tabular}




\begin{tabular}{|c|c|c|c|c|c|}
\hline Los Angeles, CA & $6,989,910$ & 3 & $9,546,597$ & 1 & $\begin{array}{r}1969-2000 \\
\text { (State data } 1982-1987)\end{array}$ \\
\hline Louisville, KY & 893,311 & 43 & $1,027,058$ & 61 & $1972-2000$ \\
\hline Memphis, TN & 848,113 & 45 & $1,138,484$ & 54 & $1972-2000$ \\
\hline Miami, FL & $1,249,884$ & 29 & $2,265,208$ & 23 & $\begin{array}{r}1969-2000 \\
\text { (State data } 1988-2000)\end{array}$ \\
\hline Middlesex, NJ & 836,616 & 47 & $1,173,533$ & 51 & $\begin{array}{r}1969-2000 \\
\text { (State data 1969-2000) }\end{array}$ \\
\hline Milwaukee, WI & $1,395,326$ & 23 & $1,501,615$ & 43 & $1969-2000$ \\
\hline Minneapolis, MN & $1,991,610$ & 13 & $2,979,245$ & 13 & $1972-2000$ \\
\hline Monmouth, NJ & 650,177 & 62 & $1,130,698$ & 56 & $\begin{array}{r}1969-2000 \\
\text { (State data } 1969-2000)\end{array}$ \\
\hline Nashville, TN & 689,753 & 57 & $1,235,818$ & 49 & $1972-2000$ \\
\hline Nassau, NY & $2,516,514$ & 9 & $2,759,245$ & 16 & $1969-2000$ \\
\hline New Haven, CT & $1,527,930$ & 19 & $1,708,336$ & 31 & $\begin{array}{r}1969-2000 \\
\text { (Average of cities) }\end{array}$ \\
\hline New Orleans, LA & $1,134,406$ & 31 & $1,337,171$ & 46 & $1972-2000$ \\
\hline New York, NY & $9,024,022$ & 1 & $9,321,820$ & 2 & $1969-2000$ \\
\hline Newark, NJ & $1,988,239$ & 14 & $2,035,127$ & 26 & $\begin{array}{r}1969-2000 \\
\text { (State data } 1969-2000)\end{array}$ \\
\hline Norfolk, VA & $1,076,672$ & 36 & $1,574,204$ & 40 & $\begin{array}{r}1972-2000 \\
\text { (State data 1973-1996) }\end{array}$ \\
\hline Oakland, CA & $1,606,461$ & 17 & $2,402,553$ & 21 & $\begin{array}{r}1969-2000 \\
\text { (State data 1969-1987) }\end{array}$ \\
\hline Oklahoma City, OK & 691,473 & 56 & $1,085,282$ & 60 & $1969-2000$ \\
\hline Orange County, CA & $1,376,796$ & 24 & $2,856,493$ & 14 & $\begin{array}{r}1969-2000 \\
\text { (State data 1982-1987) }\end{array}$ \\
\hline Orlando, FL & 510,189 & 76 & $1,655,966$ & 33 & $\begin{array}{r}1972-2000 \\
\text { (State data } 1988-2000)\end{array}$ \\
\hline Philadelphia, PA & $4,829,078$ & 5 & $5,104,291$ & 5 & $1972-2000$ \\
\hline Phoenix, AZ & $1,013,400$ & 40 & $3,276,392$ & 12 & $\begin{array}{r}1972-2000 \\
\text { (State data 1972-1987) }\end{array}$ \\
\hline Pittsburgh, PA & $2,683,385$ & 8 & $2,356,275$ & 22 & $1972-2000$ \\
\hline Portland, OR & $1,064,099$ & 37 & $1,924,591$ & 27 & $1972-2000$ \\
\hline Providence, RI & 839,909 & 46 & 964,594 & 64 & $1969-2000$ \\
\hline Raleigh-Durham, NC & 526,723 & 73 & $1,195,922$ & 50 & $1972-2000$ \\
\hline Richmond, VA & 673,990 & 60 & 999,325 & 62 & $1972-2000$ \\
\hline Riverside, CA & $1,122,165$ & 32 & $3,280,236$ & 11 & $\begin{array}{r}1969-2000 \\
\text { (State data } 1982-1987)\end{array}$ \\
\hline Rochester, NY & $1,005,722$ & 41 & $1,098,314$ & 58 & $1969-2000$ \\
\hline Sacramento, CA & 737,534 & 53 & $1,638,474$ & 35 & $\begin{array}{r}1969-2000 \\
\text { (State data } 1982-1987)\end{array}$ \\
\hline St. Louis, MO & $2,412,381$ & 10 & $2,606,023$ & 17 & $1972-2000$ \\
\hline Salt Lake City, UT & 677,500 & 58 & $1,337,221$ & 45 & $1972-2000$ \\
\hline
\end{tabular}




\begin{tabular}{|c|c|c|c|c|c|}
\hline San Antonio, TX & 892,602 & 44 & $1,599,378$ & 38 & $1972-2000$ \\
\hline \multirow[t]{2}{*}{ San Diego, CA } & $1,340,989$ & 28 & $2,824,809$ & 15 & $1969-2000$ \\
\hline & & & & & (State data 1982-1987) \\
\hline \multirow[t]{2}{*}{ San Francisco, CA } & $1,482,030$ & 20 & $1,731,716$ & 29 & $1969-2000$ \\
\hline & & & & & (State data 1982-1987) \\
\hline \multirow[t]{2}{*}{ San Jose, CA } & $1,033,442$ & 38 & $1,683,908$ & 32 & $1972-2000$ \\
\hline & & & & & (State data 1982-1987) \\
\hline \multirow[t]{2}{*}{ Scranton, PA } & 650,418 & 61 & 623,543 & 84 & $1972-2000$ \\
\hline & & & & & (State data 1983-1984) \\
\hline \multirow[t]{2}{*}{ Seattle, WA } & $1,430,592$ & 22 & $2,418,121$ & 19 & $1972-2000$ \\
\hline & & & & & (State data 1982-2000) \\
\hline Syracuse, NY & 708,325 & 55 & 731,969 & 73 & $1969-2000$ \\
\hline \multirow[t]{2}{*}{ Tampa, FL } & $1,082,821$ & 35 & $2,403,934$ & 20 & $1972-2000$ \\
\hline & & & & & (State data 1988-2000) \\
\hline Tulsa, OK & 519,537 & 74 & 804,774 & 71 & $1969-2000$ \\
\hline Washington, DC & $3,150,087$ & 7 & $4,948,213$ & 6 & $1972-2000$ \\
\hline \multirow[t]{2}{*}{ W. Palm Beach, FL } & 336,706 & 105 & $1,136,136$ & 55 & $1969-2000$ \\
\hline & & & & & (State data 1988-2000) \\
\hline
\end{tabular}

Complete data on population and income were available for all cities from 1969 to 2000.

This implies that data on income growth and income growth lagged one year were available from 1971 to 2000. Data regarding state and local taxes as a percentage of state GDP were available for all cities from 1970 to 2000 and were obtained from the Tax Foundation in Washington, D.C. Wage data from the Bureau of Labor Statistics Current Employment Statistics Survey were available for cities as described above. When city data were not available, state wage data were used in its place. When possible, the state wage data was adjusted to reflect differences between existing state wage data and existing city wage data. For MSAs that included several primary cities, the wages of the cities were averaged together to create an MSA wage as noted in Table A1.

The Other dummy variable was included for cities highly dependent on oil revenues such as New Orleans and Houston. The first variable was set at a value of 1 for boom years, 19741976 and 1979-1981, and the second variable was set at 1 for the bust years, 1985-1988. The Other dummy variables were also set at a value of 1 for the years 1992 and 1993 for the city of 
Miami to account for the impact of Hurricane Andrew.

Income and population data were obtained from the Regional Economic Information System at the University of Virginia, which derives its data from the Department of Commerce statistics.

Note: The information in the appendix is provided for the use of the referees but is probably not necessary to include in the published version of the paper. A comment noting, "A full description of the data used for analysis is available from the authors upon request," has been included in the footnotes section. 